\title{
Synthesis and evaluation of vasoconstrictor and vasorelaxant activity of Norbormide isomers
}

\author{
Margaret A. Brimble, ${ }^{* a}$ Victoria J. Muir, ${ }^{a}$ Brian Hopkins, ${ }^{b}$ and Sergio Bova ${ }^{c}$ \\ ${ }^{a}$ Department of Chemistry, University of Auckland, 23 Symonds St., Auckland, New Zealand \\ ${ }^{b}$ Landcare Research, Mt Albert Research Centre, Mt Albert Road, Private Bag 92 170, \\ Auckland, New Zealand \\ ${ }^{c}$ Department of Pharmacology and Anesthesiology, Pharmacology Division, \\ University of Padova, Padova, Italy \\ E-mail: m.brimble@auckland.ac.nz
}

(received 17 Dec 03; accepted 04 Feb 04; published on the web 10 Feb 04)

\begin{abstract}
The rat toxicant norbormide, was synthesized and six stereoisomers of norbormide were isolated and purified by chromatography in order to undertake structure-activity relationship studies with respect to vasorelaxant and vasoconstrictor properties. Isomers $\mathrm{V}, \mathrm{W}$ and $\mathrm{Y}$ behave qualitatively like the isomeric mixture of norbormide isomers showing either vasoconstrictor or vasorelaxant activities. Isomers $\mathrm{X}$ and $\mathrm{R}$ exhibit vasorelaxant effects only. These results indicate that the selective vasoconstrictor effect is stereospecific thereby suggesting the existence of a norbormide-specific receptor.
\end{abstract}

Keywords: Norbormide, maleimide, Diels-Alder reaction, rat selective toxicant

\section{Introduction}

Norbormide 1 is a compound discovered in the early 1960s that is uniquely toxic to rats and relatively harmless to other rodents and mammals. ${ }^{1,2,3}$ It exerts its lethality in the rat through mechanisms involving the control of blood pressure. Evidence suggests that norbormide acts by stimulating a number of signal transduction pathways that lead to modulation of calcium influx, presumably mediated by cell membrane receptor(s). ${ }^{4}$ Physiological studies indicate that norbormide elicits divergent tissue responses, causing selective vasoconstriction of small arteries and vasodilation of large blood vessels in the rat, whilst dilating both small and large blood vessels of other species. ${ }^{5}$ The contrasting responses to this toxin may be the key to understanding the secret of species-specificity of drug action and are therefore vital in providing opportunities for developing more species-selective pesticides. The present work was undertaken 
to characterize the pattern of actions of norbormide isomers in vitro on rat vascular smooth muscle.

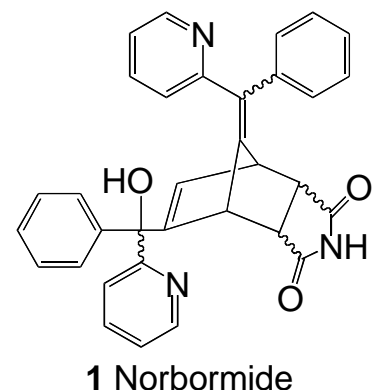

\section{Discussion}

The synthesis of norbormide $\mathbf{1}$ has previously been reported in the literature via Diels-Alder reaction of 2-fulvenylmethanol $\mathbf{2}$ with maleimide (Scheme 1). ${ }^{6,7}$ The intermediate 2fulvenylmethanol $\mathbf{2}$ in turn is available from base-induced (sodium ethoxide) reaction of cyclopentadiene with 2-benzoylpyridine in ethanol, carefully controlling the reaction conditions to ensure predominance of the desired 2-fulvenylmethanol 2 over the 6,6-diarylfulvene byproduct. $^{8}$ 2-Fulvenylmethanol 2 was obtained as a mixture of cis and trans stereoisomers that were not separated. Subsequent reaction of 2-fulvenylmethanol 2 with maleimide introduces additional asymmetry such that there are eight possible stereoisomers of norbormide $\mathbf{1}$, each of which is a racemate (Figure 1).

In addition to using the endo-exo convention, isomers in which the pyridyl group attached to the double bond is on the side opposite the carbinol group is assigned the trans configuration. Isomers in which the hydroxyl group is in the same plane as the methylene double bond (and above the norbornene ring) and in which the pyridyl group is on the same side as H6 are assigned as erythro. When initial stereochemical assignments of the norbormide isomers were made using ${ }^{1} \mathrm{H}$ n.m.r. spectroscopy ${ }^{6}$ individual isomers were given arbitrary designations as $\mathrm{R}, \mathrm{S}, \mathrm{T}, \mathrm{U}, \mathrm{V}$, $\mathrm{W}, \mathrm{X}, \mathrm{Y}, \mathrm{Z}$ and these have been included herein for comparative purposes.

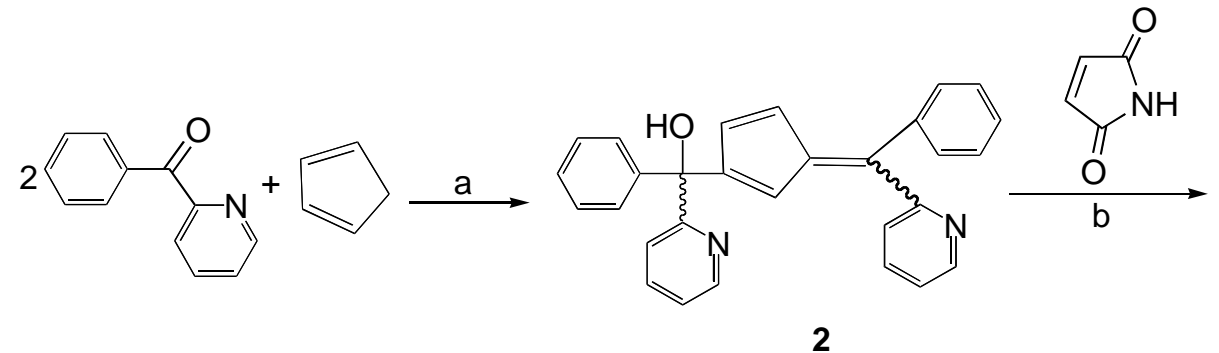

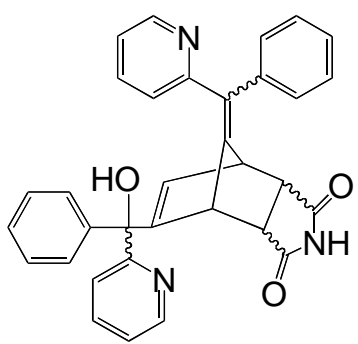

1

Reagents and Conditions: (a) NaOEt, EtOH, $5^{\circ} \mathrm{C}, 30$ min then $10-13{ }^{\circ} \mathrm{C}, 1.5 \mathrm{~h}$; (b) xylene, $80{ }^{\circ} \mathrm{C}, 12 \mathrm{~h}$.

\section{Scheme 1}


Diels-Alder addition of maleimide to 2-fulvenylmethanol 2 was carried by heating in xylene at $80{ }^{\circ} \mathrm{C}$ for $12 \mathrm{~h}$. The endo isomers $\mathbf{1 a}, \mathbf{1 b}, \mathbf{1 c}, \mathbf{1 d}$ dominated the exo isomers $1 \mathbf{e}, \mathbf{1 f}, \mathbf{1 g}, \mathbf{1 h}$ in the crude product mixture and recrystallization of the crude product from ethyl acetate afforded material enriched in the endo isomers 1a, 1b, 1c,1d. Further purification of the endo-enriched material by column chromatography afforded pure samples of endo isomers $\mathbf{1 a}, \mathbf{1 b}$, and 1d. Exoisomer $1 \mathrm{~g}$ was obtained by direct column chromatography of the intial crude product mixture. Exo-isomers 1e and 1f were obtained by careful column chromatography of the material obtained by concentration of the mother liquors obtained from recrystallization of the crude product from ethyl acetate. Pure samples of endo-isomer 1c and exo-isomer $\mathbf{1 h}$ were not obtained in the present work, however, ${ }^{1} \mathrm{H}$ NMR data was obtained for these isomers from spectra of isomeric mixtures that contained these isomers as impurities.

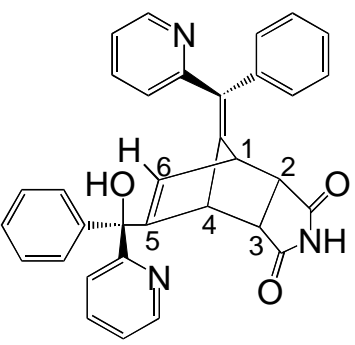

$1 \mathrm{a}$

cis-endo-threo

$\mathrm{V}$ isomer

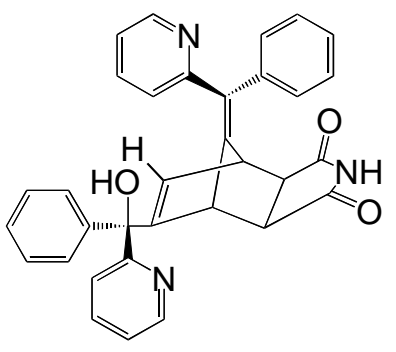

$1 e$

cis-exo-threo

$\mathrm{R}$ isomer

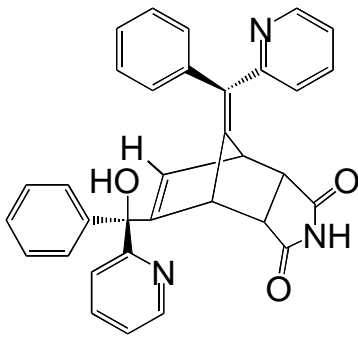

$1 b$

trans-endo-threo

$\mathrm{Y}$ isomer

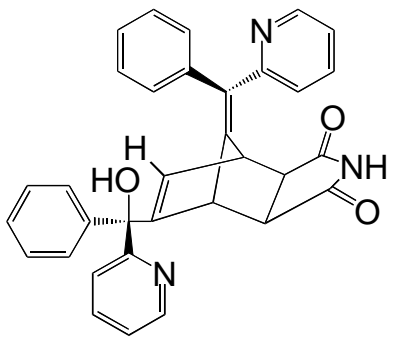

$1 f$

trans-exo-threo

$\mathrm{T}$ isomer

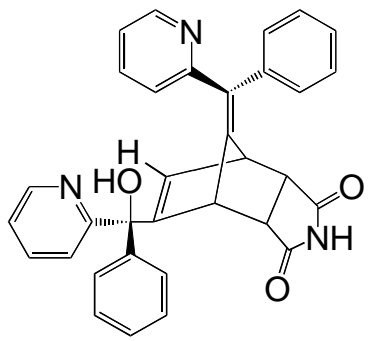

1c

cis-endo-erythro

$\mathrm{U}$ isomer

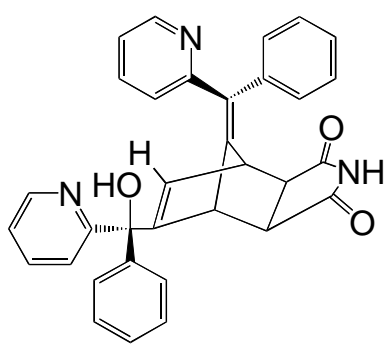

$1 \mathrm{~g}$

cis-exo-erythro

$\mathrm{X}$ isomer

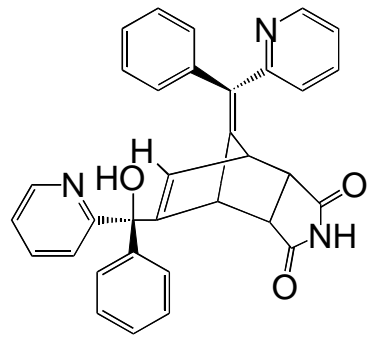

$1 d$

trans-endo-erythro

$\mathrm{W}$ isomer

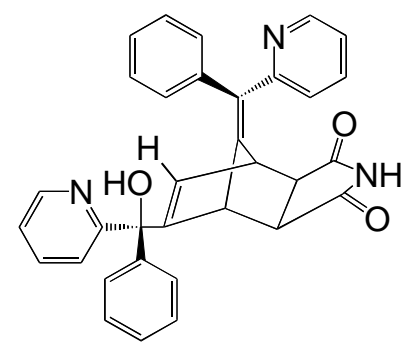

1h

trans-exo-erythro

$\mathrm{S}$ isomer

Figure 1. Stereoisomers of Norbormide (1).

The stereochemistry of the six racemic diastereomers of norbormide thus obtained was assigned by comparing the newly acquired high field ${ }^{1} \mathrm{H}$ NMR data with the older lower field literature values. ${ }^{6,8}$ In addition ${ }^{13} \mathrm{C}$ NMR data and two dimensional COSY, HETCOR, HMBC and HMBQ spectra aided the definitive assignment of stereochemistry. Comprehensive ${ }^{1} \mathrm{H}$ and ${ }^{13} \mathrm{C}$ n.m.r. data for isomers $\mathbf{1 a}, \mathbf{1 b}, \mathbf{1 d}, \mathbf{1 e}, \mathbf{1 f}, \mathbf{1 g}$ are included in the experimental section.

Endo/exo assignments were made on the basis of coupling constants. The $J_{1,2}$ coupling constants for the exo protons of endo isomers are known to be larger than for the corresponding 
endo protons of exo isomers. ${ }^{9}$ In norbornene $J_{1,2 e x o}=3.66 \mathrm{~Hz}$ and $J_{1,2 e n d o}=0.55 \mathrm{~Hz} .{ }^{10}$ Values of $J_{1,2 e x o}=3.0-5.0 \mathrm{~Hz}$ have been found for analogues of norbornene and norbornane. ${ }^{10}$ This corresponds with the values obtained for the endo isomers of norbormide 1a, 1b, 1c, 1d which have $J_{1,2 \text { exo }}=4.8-5.0 \mathrm{~Hz}$ and the exo isomers $1 \mathbf{e}, \mathbf{1 f}, \mathbf{1 g}, \mathbf{1 h}$ have $J_{1,2 e n d o}=0.8 \mathrm{~Hz}$ (Table 1). It is also known that exo 2,3 protons are deshielded relative to endo 2,3 protons. ${ }^{9}$ In the norbormide isomers the exo 2,3 protons of the endo isomers resonate at $\delta 3.38-3.69 \mathrm{ppm}$ and the endo 2,3 protons of the exo isomers resonate at $\delta 2.90-3.42$ ppm thus confirming the assignments based on coupling constants.

Table 1. ${ }^{1} \mathrm{H}$ NMR $J_{1,2 \text { exo }}$ and $J_{1,2 \text { endo }}$ Coupling constants for norbormide stereoisomers

\begin{tabular}{cccc}
\hline & Isomer & $J_{1,2}(\mathrm{~Hz})$ & $J_{2,3}(\mathrm{~Hz})$ \\
\hline endo & $\mathbf{1 a}(\mathrm{V})$ & 4.9 & 4.6 \\
& $\mathbf{1 b}(\mathrm{Y})$ & 5.0 & 4.6 \\
& $\mathbf{1 c}(\mathrm{U})$ & 4.8 & 4.3 \\
& $\mathbf{1 d}(\mathrm{W})$ & 5.0 & 4.5 \\
\hline exo & $\mathbf{1 e}(\mathrm{R})$ & 0.8 & 0.9 \\
& $\mathbf{1 f}(\mathrm{T})$ & 0.8 & 0.9 \\
& $\mathbf{1 g}(\mathrm{X})$ & 0.8 & 0.8 \\
& $\mathbf{1 h}(\mathrm{S})$ & 0.8 & 0.9 \\
\hline
\end{tabular}

In analogues of norbormide, Mohrbacher and co-workers ${ }^{6}$ showed that when two phenyl groups are present $\mathrm{H} 1$ and $\mathrm{H} 4$ resonate at approximately $\delta 3.62 \mathrm{ppm}$ and when two pyridyl groups are present $\mathrm{H} 1$ and $\mathrm{H} 4$ resonate further downfield at $\delta 3.96-4.05 \mathrm{ppm}$. Hence, the pyridyl group has a stronger deshielding effect than the phenyl group at C8. In the isomers where the H1 resonance appears downfield from $\mathrm{H} 4$, the pyridyl group is deshielding $\mathrm{H} 1$, indicating that the pyridyl group is above $\mathrm{H} 1$ and hence the isomer must be trans (Table 2).

Table 2. ${ }^{1} \mathrm{H}$ NMR Chemical shifts for $\mathrm{H} 1$ and $\mathrm{H} 4$ resonances of norbormide stereoisomers

\begin{tabular}{cccc}
\hline & Isomer & $\delta \mathrm{H} 1(\mathrm{ppm})$ & $\delta \mathrm{H} 4(\mathrm{ppm})$ \\
\hline \multirow{4}{*}{ cis } & $\mathbf{1 a}(\mathrm{V})$ & 3.86 & 4.33 \\
& $\mathbf{1 c}(\mathrm{U})$ & 3.86 & 4.15 \\
& $\mathbf{1 e}(\mathrm{R})$ & 3.74 & 4.08 \\
& $\mathbf{1 g}(\mathrm{X})$ & 3.78 & 4.00 \\
\hline \multirow{2}{*}{ trans } & $\mathbf{1 b}(\mathrm{Y})$ & 4.47 & 3.96 \\
& $\mathbf{1 d}(\mathrm{W})$ & 4.44 & 3.64 \\
& $\mathbf{1 f}(\mathrm{T})$ & 4.37 & 3.79 \\
& $\mathbf{1 h}(\mathrm{S})$ & 4.34 & 3.50 \\
\hline
\end{tabular}


The X-ray structures of the cis-endo-threo isomer $1 \mathbf{a}^{11}$ and the cis-exo-erythro $\mathbf{1 g}^{12}$ have been reported and allowed assignment of the threo and erythro configurations by comparison of the chemical shifts observed for H6 (Table 3). The pyridyl group attached to the carbinol carbon can deshield H6 more strongly when the arrangement about the carbinol carbon is erythro. Hence $\mathrm{H} 6$ in the cis-exo-erthyro isomer $1 \mathrm{~g}$ resonates further downfield at $\delta 6.16 \mathrm{ppm}$ compared to $\delta 5.64 \mathrm{ppm}$ in isomer 1a. Erythro/threo designations were assigned on this basis.

Table 3. ${ }^{1} \mathrm{H}$ NMR Chemical shifts for $\mathrm{H} 6$ resonances of norbormide stereoisomers

\begin{tabular}{ccc}
\hline & Isomer & $\delta$ H6 (ppm) \\
\hline threo & $\mathbf{1 a}(\mathrm{V})$ & 5.64 \\
& $\mathbf{1 b}(\mathrm{Y})$ & 5.66 \\
& $\mathbf{1 e}(\mathrm{R})$ & 5.75 \\
& $\mathbf{1 f}(\mathrm{T})$ & 5.76 \\
\hline erythro & $\mathbf{1 c}(\mathrm{U})$ & 6.07 \\
& $\mathbf{1 d}(\mathrm{W})$ & 6.08 \\
& $\mathbf{1 g}(\mathrm{X})$ & 6.16 \\
& $\mathbf{1 h}(\mathrm{S})$ & 6.20 \\
\hline
\end{tabular}

The interesting and unique properties of norbormide prompted us to separate the isomers and to characterize their contractile and relaxing effects on rat caudal and aortic vascular smooth muscle. As evidenced in Figure 2, three of the six isomers tested, namely the V, Y, and $\mathrm{W}$ isomers maintained the contractile activity shown by the stereoisomeric mixture. The $\mathrm{EC}_{50}$ values for these three isomers were very similar to that of steroisomeric mixture (Table 4). Also, the maximal developed tension expressed either as absolute values $(\mathrm{mg})$ or as a percent of the maximal response to $\mathrm{KCl}$ was quite similar to that of the steroisomeric mixture (NRB) (Table 4). For any of these isomers $\mathrm{V}, \mathrm{Y}$ or $\mathrm{W}$, its maximal effect was greater compared to the maximal $\mathrm{KCl}$-induced contraction. On the other hand, differences between these contracting isomers $\mathrm{V}, \mathrm{Y}$ and $\mathrm{W}$ were observed in their relaxant action tested in rat aorta (Figure 2 ) precontracted with $\mathrm{KCl}$. Of particular interest in this respect is isomer $\mathrm{V}$ that, at the same concentration that induced the maximal contraction in the rat caudal artery, relaxes $\mathrm{KCl}$ contraction by only $25 \%$ (Figure 2). Therefore, the $\mathrm{V}$ isomer seems to be almost a "pure" contractile isomer, almost lacking in relaxing effect (Table 4). 

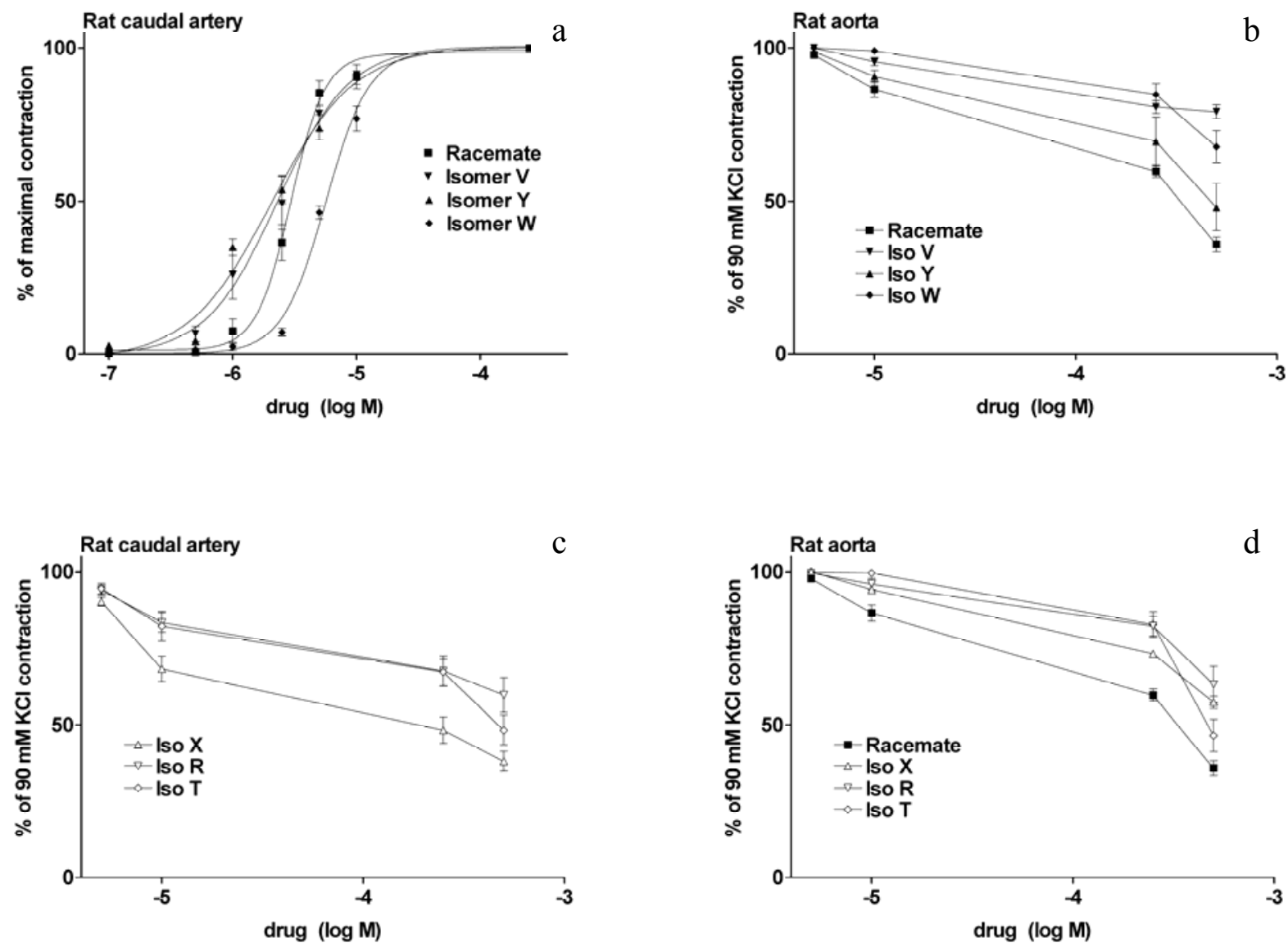

Figure 2. Illustrating (a) the contraction of the rat caudal artery, (b) contractile effects on the rat aorta, (c) vasorelaxation of the rat caudal artery, (d) vasorelaxation of the rat aorta.

Three of the six isomers tested, namely isomers $\mathrm{X}, \mathrm{R}$, and $\mathrm{T}$ showed only vasorelaxation effects (Figure 2). This effect was observed not only in rat aorta, which is not contracted by norbormide, but also in rat caudal artery, which is contracted by the drug (Figure 2). These results clearly demonstrate that: i) the vasorelaxant and the vasoconstrictor effects of norbormide are mediated by different binding sites and ii) the vasoconstrictor effect is strongly stereospecific indicating the involvement of a receptor in its development. Unfortunately, among the tested isomers, none showed "pure" vasoconstrictor activity. Such a compound would be of great help in order to characterize the receptor involved in norbormide-induced vasoconstriction. Hopefully, the synthesis of analogues of the $\mathrm{V}$ isomer may lead to compounds with greater potency than norbormide that are also endowed with only selective vasoconstrictor activity. 
Table 4. Activity of compounds

\begin{tabular}{|c|c|c|c|c|c|}
\hline Compound & $\begin{array}{c}\text { Max } \\
\text { contractile } \\
\text { effect }(\mathrm{mg}) \\
\text { (rat caudal art.) } \\
\text { mean } \pm \mathrm{ES}, \\
\mathrm{n}=15\end{array}$ & $\begin{array}{l}\mathrm{IC}_{50}(\mu \mathrm{M}) \\
\text { mean } \pm \mathrm{ES}\end{array}$ & $\begin{array}{c}\text { Contractile } \\
\text { effect } \\
\text { as } \% \text { of } \mathrm{KCl} \\
\text { contraction } \\
\text { (rat caudal art.) } \\
\text { mean, } \mathrm{n}=15\end{array}$ & $\begin{array}{c}\text { Max } \% \\
\text { relaxation } \\
\text { of } \mathrm{KCl} \\
\text { contraction } \\
\text { (rat aorta) } \\
\text { mean } \pm \mathrm{ES}, \\
\mathrm{n}=15\end{array}$ & $\begin{array}{c}\text { Max \% } \\
\text { relaxation } \\
\text { of } \mathrm{KCl} \\
\text { contraction } \\
\text { (rat caudal art.) } \\
\text { mean } \pm \mathrm{ES}, \\
\mathrm{n}=15\end{array}$ \\
\hline $\mathbf{N R B}^{\#}$ & $2722 \pm 262$ & $2.93 \pm 0.02$ & 132 & $64 \pm 2.4$ & \\
\hline $1 \mathrm{a}(\mathrm{V})$ & $2483 \pm 102$ & $2.30 \pm 0.04$ & 130 & $21 \pm 2.2$ & \\
\hline $1 b(Y)$ & $2683 \pm 135$ & $2.06 \pm 0.08$ & 136 & $52 \pm 7.6$ & \\
\hline $\mathbf{1 d}(\mathrm{W})$ & $2172 \pm 307$ & $5.64 \pm 0.02$ & 134 & $33 \pm 5.2$ & \\
\hline $1 \mathrm{e}(\mathrm{R})$ & no activity & & & $37 \pm 5.8$ & $40 \pm 5.6$ \\
\hline $\mathbf{1 f}(\mathrm{T})$ & no activity & & & $54 \pm 5.3$ & $52 \pm 4.9$ \\
\hline $\lg (X)$ & no activity & & & $43 \pm 2.0$ & $62 \pm 3.3$ \\
\hline
\end{tabular}

${ }^{\#}$ Mixture of stereoisomers of norbormide $\mathbf{1}$.

\section{Experimental Section}

\section{In vitro assays on vascular smooth muscle}

All animal research was performed according to approved procedures from the animal ethics committee of the University of Padova. Male Sprague-Dawley rats weighing 250-300 g were killed by cervical dislocation and the aorta and the ventral caudal artery were removed, carefully cleaned from the connective tissue, and cut into rings of $2 \mathrm{~mm}$ length. The endothelium was mechanically removed by rubbing the lumen of the rings with a rough-surfaced tungsten wire. The rings were vertically suspended between $100 \mu \mathrm{M}$ o.d. tungsten wires in organ baths filled with $15 \mathrm{ml}$ of physiological salt solution of the following composition (mM): $\mathrm{NaCl} 125, \mathrm{KCl} 5$, $\mathrm{CaCl}_{2} 1, \mathrm{MgSO}_{4} 1, \mathrm{KH}_{2} \mathrm{PO}_{4} 1.2, \mathrm{NaHCO}_{3} 25$, glucose 11 , at $\mathrm{pH} 7.35$, maintained at $37^{\circ} \mathrm{C}$ and bubbled with $95 \% \mathrm{O}_{2}$ and $5 \% \mathrm{CO}_{2}$. Tension was recorded on a pen recorder (Ugo Basile, Varese, Italy) via an isometric force displacement transducer (Ugo Basile). Rings were stretched passively to impose a resting tension of $1.5 \mathrm{~g}$ and $1.0 \mathrm{~g}$ for the caudal artery and the aortic rings, respectively. The rings were allowed to equilibrate for $60 \mathrm{~min}$ then the responsiveness of each ring was tested by applying a maximally effective concentration of either phenylephrine $(10 \mu \mathrm{M})$ or $\mathrm{KCl}(90 \mathrm{mM})$. To verify the absence of the endothelium, the rings were contracted with $1 \mu \mathrm{M}$ phenylephrine and then exposed to $2 \mu \mathrm{M}$ carbamylcholine. The absence of the endothelium was revealed by the lack of carbamylcholine-induced relaxation. Phenylephrine and carbamylcholine were dissolved in doubly distilled water, the individual norbormide isomers and the 
stereoisomeric norbormide mixture were dissolved in dimethylformamide (DMF) to obtain $50 \mathrm{mM}$ stock solutions.

To test the activity of the isomers, the following experimental protocol was applied: 1) the isomers $(1-50 \mu \mathrm{M})$ were initially tested for vasoconstrictor activity in resting caudal artery rings; 2) if the vasoconstrictor effect was not present, then they were tested, in the same ring, for the vasorelaxant effect. All the isomers were additionally tested for the vasorelaxant effect on rat aorta. The vasorelaxant effect of the isomers was evaluated by exposing $90 \mathrm{mM} \mathrm{KCl}-$ precontracted vessels to cumulative concentrations of the compounds (1-50 $\mu \mathrm{M})$.

General Procedures. All reactions were carried out under a positive pressure of nitrogen. Flash chromatography was performed using Merck Kieselgel 60 (230-400 mesh) with the indicated solvents. Thin layer chromatography (TLC) was carried out on precoated silica plates (Merck Kieselgel $60 \mathrm{~F}_{254}$ ) and compounds were visualized by UV fluorescence or by staining with vanillin in methanolic sulfuric acid and heating. ${ }^{1} \mathrm{H}$ and ${ }^{13} \mathrm{C}$ NMR spectra were obtained using a Bruker Avance 300 spectrometer. All chemical shifts are given in parts per million ( $\mathrm{ppm})$ downfield from tetramethylsilane as internal standard $\left({ }^{1} \mathrm{H}\right)$ or relative to $\mathrm{CDCl}_{3}\left({ }^{13} \mathrm{C}\right)$ and $J$ values are given in $\mathrm{Hz} .{ }^{1} \mathrm{H}$ NMR data are tabulated as s, singlet; d, doublet; t, triplet; q, quartet, $\mathrm{m}$, multiplet, br, broad. High resolution mass spectra were recorded using a VG70-SE spectrometer operating at nominal accelerating voltage of $70 \mathrm{eV}$. Chemical ionisation (CI) mass spectra were obtained with ammonia as the reagent gas.

cis, trans- $\alpha$-Phenyl- $\alpha$-[6-phenyl-6-(2-pyridyl)-2-fulvenyl]-2-pyridinemethanol ${ }^{8}$ (2). To a solution of sodium ethoxide $(0.13 \mathrm{~mol})$ and 2-benzoylpyridine $(45.8 \mathrm{~g}, 0.25 \mathrm{~mol})$ in absolute ethanol $(125 \mathrm{~mL})$ at $5^{\circ} \mathrm{C}$ under nitrogen was added drop-wise freshly distilled cyclopentadiene $(10.7 \mathrm{~mL}$, $0.13 \mathrm{~mol}$ ) over a $30 \mathrm{~min}$ period. The mixture was stirred under nitrogen for $1.5 \mathrm{~h}$ at $10-13^{\circ} \mathrm{C}$, and left standing overnight. The red-orange crystalline product was collected by filtration and washed with cold alcohol. Recrystallization from ethyl acetate gave a mixture of geometric isomers of 2 (39.7 g, 76\%) as orange crystals: Mp $160-165^{\circ} \mathrm{C}\left(1 \mathrm{lit} .{ }^{6,7} 138-160^{\circ} \mathrm{C}, 173-176^{\circ} \mathrm{C}\right) ;{ }^{1} \mathrm{H}$ NMR $(400 \mathrm{MHz}$; $\left.\mathrm{CDCl}_{3}\right) \delta_{\mathrm{H}} 5.99(0.4 \mathrm{H}, \mathrm{t}, J 1.9$, trans $\mathrm{H} 1), 6.02(0.6 \mathrm{H}, \mathrm{t}, J 1.9$, cis $\mathrm{H} 1), 6.17(0.6 \mathrm{H}$, s, cis $\mathrm{OH}), 6.18$ $(0.4 \mathrm{H}$, s, trans $\mathrm{OH}), 6.35(0.6 \mathrm{H}, \mathrm{dd}, J 5.4,2.1$, cis $\mathrm{H} 4), 6.40(0.4 \mathrm{H}, \mathrm{dd}, J$ 5.4, 2.1, trans $\mathrm{H} 4), 6.57$ $(1 \mathrm{H}, \mathrm{m}, \mathrm{H} 3), 7.10-7.70(16 \mathrm{H}, \mathrm{m}, \mathrm{Ar}), 8.52(1 \mathrm{H}, \mathrm{bd}, J 4.2, \alpha \mathrm{Pyr}), 8.58$ (0.6H, bd, J 4.7, cis $\alpha \mathrm{Pyr})$, $8.67(0.4 \mathrm{H}$, bd, J 3.2, trans $\alpha \mathrm{Pyr}) ;{ }^{1} \mathrm{H}$ NMR $\left(400 \mathrm{MHz} ; \mathrm{CDCl}_{3}\right) \delta_{\mathrm{C}} 78.15$ (trans $\left.\mathrm{C}-\mathrm{OH}\right), 78.2$ (cis C$\mathrm{OH}), 121.3(\mathrm{CH}, \mathrm{Ar}), 121.4(\mathrm{CH}, \mathrm{Ar}), 122.3(\mathrm{CH}, \mathrm{Ar}), 122.4(\mathrm{CH}, \mathrm{Ar}), 122.75(\mathrm{CH}, \mathrm{Ar}), 125.2(\mathrm{CH}$, Ar), $125.6(\mathrm{CH}$, cis $\mathrm{C} 4), 127.1(\mathrm{CH}$, trans $\mathrm{C} 4), 127.15(\mathrm{CH}, \mathrm{Ar}), 127.4(\mathrm{CH}, \mathrm{Ar}), 127.5(\mathrm{CH}, \mathrm{Ar})$, $127.5(\mathrm{CH}, \mathrm{Ar}), 127.6(\mathrm{CH}, \mathrm{Ar}), 127.9(\mathrm{CH}, \mathrm{Ar}), 128.1(\mathrm{CH}, \mathrm{Ar}), 128.6(\mathrm{CH}, \mathrm{Ar}), 131.65(\mathrm{CH}$, cis C3), $131.7(\mathrm{CH}$, trans $\mathrm{C} 3), 133.9(\mathrm{CH}, \mathrm{Ar}), 134.0(\mathrm{CH}, \mathrm{Ar}), 135.6(\mathrm{CH}, \mathrm{Ar}), 135.7(\mathrm{CH}, \mathrm{Ar})$, 136.55 (Ch, Ar), 136.6 (CH, Ar), 139.9 (quat.), 140.1 (quat.), 144.8 (quat.), 144.9 (quat.), 147.6 (CH, Ar), 148.8 (quat.), 148.95 (quat.), $149.4(\mathrm{CH}, \mathrm{Ar}), 149.5(\mathrm{CH}, \mathrm{Ar}), 152.75(\mathrm{CH}, \mathrm{Ar}), 152.80$ (CH, Ar), 158.9 (CH, Ar), $159.2(\mathrm{CH}, \mathrm{Ar}), 162.0(\mathrm{CH}, \mathrm{Ar}), 162.1(\mathrm{CH}, \mathrm{Ar}) ; \mathrm{m} / \mathrm{z}\left(\mathrm{EI}^{+}\right) 414.1736\left(\mathrm{M}^{+}\right.$. $\mathrm{C}_{29} \mathrm{H}_{22} \mathrm{~N}_{2} \mathrm{O}$ requires 414.1736). 


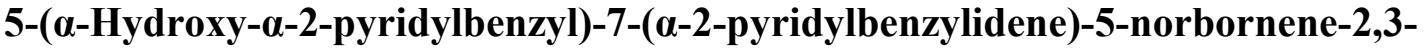

dicarboximide $^{6}$ (1). Fulvenyl methanol $2(0.5 \mathrm{~g}, 1.2 \mathrm{mmol})$ and maleimide $(0.12 \mathrm{~g}, 1.2 \mathrm{mmol})$ were combined in xylene $(5 \mathrm{~mL})$ and the solution was heated at $80^{\circ} \mathrm{C}$ with stirring for $12 \mathrm{~h}$. The reaction was cooled in an ice bath and filtered to give an isomeric mixture of 1 as a cream solid (0.55 g, 90\%): Mp 212-215 ${ }^{\circ} \mathrm{C}$ (lit. $\left.{ }^{8,13} 190-198{ }^{\circ} \mathrm{C}, 209-211{ }^{\circ} \mathrm{C}\right) ; \mathrm{m} / \mathrm{z}\left(\mathrm{FAB}^{+}\right) 511.1890\left(\mathrm{M}^{+}\right.$. $\mathrm{C}_{23} \mathrm{H}_{25} \mathrm{~N}_{3} \mathrm{O}_{3}$ requires 511.1896). ${ }^{1} \mathrm{H} \mathrm{NMR}$ and ${ }^{13} \mathrm{C} \mathrm{NMR}$ data for the individual isomers are reported below.

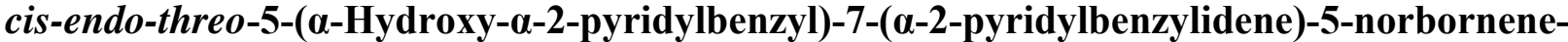

2,3-dicarboximide (1a) (V). The above isomeric mixture of 1 was recrystallized from ethyl acetate to give a mixture of the endo isomers $\mathbf{1 a}, \mathbf{1 b}, \mathbf{1 c}$ and $\mathbf{1 d}$. The recrystallized material was further purified by repeated column chromatography (ethyl acetate/ acetic acid 95:5) to give a sample containing 1a and 1d. This sample was again further purified by repeated column chromatography (ethyl acetate/ chloroform, 7:3), then recrystallized from ethyl acetate to give isomer 1a as a white solid: $\mathrm{Mp} 224-226{ }^{\circ} \mathrm{C}$ (lit. ${ }^{6} 225-226.5{ }^{\circ} \mathrm{C} \mathrm{dec}$.); ${ }^{1} \mathrm{H}$ NMR (400 MHz; $\mathrm{CDCl}_{3}$ ) $\delta_{\mathrm{H}}: 3.52(1 \mathrm{H}, \mathrm{dd}, J$ 7.9, 4.9, H2), 3.65 (1H, dd, $J$ 7.9, 4.6, H3), 3.86 (1H, m, H1), 4.33 (1H, dt, $J$ 4.6, 1.4, H4), 5.64 (1H, dd, J 3.3, 1.2, H6), 5.88 (1H, s, OH), 6.78-7.65 (17H, m, Ar +NH), 8.47 $(1 \mathrm{H}, \mathrm{m}, \alpha \mathrm{Pyr}), 8.51(1 \mathrm{H}, \mathrm{m}, \alpha \mathrm{Pyr}) ;{ }^{13} \mathrm{C} \mathrm{NMR}\left(100 \mathrm{MHz} ; \mathrm{CDCl}_{3}\right) \delta_{\mathrm{C}}: 45.9(\mathrm{C} 3), 46.0(\mathrm{C} 1), 47.9$ (C2), 49.2 (C4), 77.7 (quat., C-OH) 121.8 (CH, Ar), 122.0 (CH, Ar), 122.5 (CH, Ar), 124.1 (CH, Ar), 127.3 (CH, Ar), 127.5 (CH, Ar), 127.9 (quat.), $128.0(\mathrm{CH}, \mathrm{Ar}), 128.4(\mathrm{CH}, \mathrm{Ar}), 129.4(\mathrm{CH}$, Ar), 129.4 (quat.), 129.5 (C6), 135.9 (CH, Ar), 136.4 (CH, Ar), 138.6 (quat.), 142.9 (quat.), 147.8 $(\mathrm{CH}, \mathrm{Ar}), 149.4$ (CH, Ar), 154.8 (quat.), 155.6 (quat.), 158.1 (quat.), 160.75 (quat.), 176.7 (quat., $\mathrm{C}=\mathrm{O}$ ), 176.4 (quat., $\mathrm{C}=\mathrm{O}$ ); HRMS m/z $\left(\mathrm{EI}^{+}\right)$: $511.1892\left(\mathrm{M}^{+} . \mathrm{C}_{23} \mathrm{H}_{25} \mathrm{~N}_{3} \mathrm{O}_{3}\right.$ requires 511.1955).

trans-endo-threo-5-( $\alpha$-Hydroxy- $\alpha-2$-pyridylbenzyl)-7-( $\alpha$-2-pyridylbenzylidene)-5-

norbornene-2,3-dicarboximide (1b) (Y). The above isomeric mixture of 1 was recrystallized from ethyl acetate to give a mixture of the endo isomers $\mathbf{1 a}, \mathbf{1 b}, \mathbf{1 c}$ and $\mathbf{1 d}$. The recrystallized material was purified by repeated column chromatography (ethyl acetate/ acetic acid 95:5) to give a sample containing 1b and 1c. This material was then further purified by repeated column chromatography (ethyl acetate/ chloroform 7:3) and recrystallized from ethyl acetate to give isomer 1b as a white solid: Mp 193-196 ${ }^{\circ} \mathrm{C}$ (lit. $\left.{ }^{6} 192-195{ }^{\circ} \mathrm{C}\right) ;{ }^{1} \mathrm{H}$ NMR $\left(400 \mathrm{MHz} ; \mathrm{CDCl}_{3}\right) \delta_{\mathrm{H}}$ : 3.41 (1H, dd, J 7.8, 4.6, H3), 3.69 (1H, dd, J 7.8, 5.0, H2), 3.96 (1H, dt, J 4.6, 1.4, H4), 4.47 (1H, m, H1), $5.66(1 \mathrm{H}, \mathrm{dd}, J 3.3,1.2, \mathrm{H} 6), 5.84(1 \mathrm{H}, \mathrm{s}, \mathrm{OH}), 6.85-7.65(17 \mathrm{H}, \mathrm{m}, \mathrm{Ar}+\mathrm{NH}), 8.50(1 \mathrm{H}$, $\mathrm{m}, \alpha \mathrm{Pyr}), 8.62(1 \mathrm{H}, \mathrm{m}, \alpha \mathrm{Pyr}) ;{ }^{13} \mathrm{C} \mathrm{NMR}\left(100 \mathrm{MHz} ; \mathrm{CDCl}_{3}\right) \delta_{\mathrm{C}}: 45.7$ (C1), $46.5(\mathrm{C} 3), 47.4(\mathrm{C} 2)$, 49.5 (C4), 77.6 (quat., C-OH), 121.75 (CH, Ar), 122.0 (CH, Ar), 122.5 (CH, Ar), 124.4 (CH, Ar), 127.35 (CH, Ar), 127.55 (CH, Ar), $127.6(\mathrm{CH}, \mathrm{Ar}), 127.9$ (quat.), $128.2(\mathrm{CH}, \mathrm{Ar}), 128.3(\mathrm{CH}$, Ar), 129.4 (CH, Ar), 130.3 (C6), 136.0 (CH, Ar), 136.3 (CH, Ar), 136.4 (quat.), 142.5 (quat.), 147.9 (CH, Ar), 149.2 (CH, Ar), 153.9 (quat.), 155.1 (quat.), 158.3 (quat.), 160.7 (quat.), 176.4 (quat., $\mathrm{C}=\mathrm{O}$ ), 176.6 (quat., $\mathrm{C}=\mathrm{O}$ ).

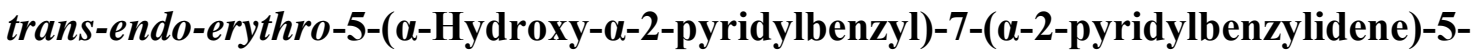
norbornene-2,3-dicarboximide (1d) (W). The above isomeric mixture of 1 was recrystallized from ethyl acetate to give a mixture of the endo isomers $\mathbf{1 a}, \mathbf{1 b}, \mathbf{1 c}$ and $\mathbf{1 d}$. The recrystallized 
material was purified by repeated column chromatography (ethyl acetate/ chloroform 7:3) then recrystallized from ethyl acetate/ hexane to give isomer $1 \mathbf{d}$ as a cream solid: Mp $184-185^{\circ} \mathrm{C}$ (lit. ${ }^{6}$ 180-183 $\left.{ }^{\circ} \mathrm{C}\right) ;{ }^{1} \mathrm{H}$ NMR $\left(400 \mathrm{MHz} ; \mathrm{CDCl}_{3}\right) \delta_{\mathrm{H}}: 3.38(1 \mathrm{H}, \mathrm{dd}, J$ 7.9, 4.5, H3), $3.64(1 \mathrm{H}, \mathrm{dt}, J 4.5$, 1.4, H4), $3.67(1 \mathrm{H}, \mathrm{dd}, J 7.9,5.0, \mathrm{H} 2), 4.44(1 \mathrm{H}, \mathrm{m}, \mathrm{H} 1), 5.64(1 \mathrm{H}, \mathrm{s}, \mathrm{OH}), 6.08(1 \mathrm{H}, \mathrm{dd}, J 3.3$, 1.3, H6), 6.89-7.60 (17H, m, Ar+NH), $8.50(1 \mathrm{H}, \mathrm{m}, \alpha \mathrm{Pyr}), 8.62(1 \mathrm{H}, \mathrm{m}, \alpha \mathrm{Pyr}) ;{ }^{13} \mathrm{C}$ NMR $(100$ $\left.\mathrm{MHz} ; \mathrm{CDCl}_{3}\right) \delta_{\mathrm{C}}$ : $45.6(\mathrm{C} 1), 46.3(\mathrm{C} 3), 47.8(\mathrm{C} 2), 49.5(\mathrm{C} 4), 77.7$ (quat., $\left.\mathrm{C}-\mathrm{OH}\right), 121.8(\mathrm{CH}, \mathrm{Ar})$, 122.0 (CH, Ar), 122.1 (quat.), $122.6(\mathrm{CH}, \mathrm{Ar}), 124.3(\mathrm{CH}, \mathrm{Ar}), 126.9(\mathrm{CH}, \mathrm{Ar}), 127.4(\mathrm{CH}, \mathrm{Ar})$, $127.9(\mathrm{CH}, \mathrm{Ar}), 128.3(\mathrm{CH}, \mathrm{Ar}), 129.25(\mathrm{CH}, \mathrm{Ar}), 133.6(\mathrm{C} 6), 136.05(\mathrm{CH}, \mathrm{Ar}), 136.7(\mathrm{CH}, \mathrm{Ar})$, 138.6 (quat.), 143.1 (quat.), $148.3(\mathrm{CH}, \mathrm{Ar}), 149.3(\mathrm{CH}, \mathrm{Ar}), 153.2$ (quat.), 155.4 (quat.), 158.2 (quat.), 160.7 (quat.), 176.2 (quat., $\mathrm{C}=\mathrm{O}$ ), 176.6 (quat., $\mathrm{C}=\mathrm{O}$ ).

cis-exo-erythro-5-( $\alpha$-Hydroxy- $\alpha$-2-pyridylbenzyl)-7-( $\alpha$-2-pyridylbenzylidene)-5-norbornene2,3-dicarboximide (1g) (X). The initial crude sample of $\mathbf{1}$ was purified by repeated column chromatography (ethyl acetate/ chloroform 7:3). Recrystallization from ethyl acetate gave isomer 1 gas a white solid: Mp 237-239 ${ }^{\circ} \mathrm{C}$ (lit. $\left.{ }^{6} 239{ }^{\circ} \mathrm{C}\right) ;{ }^{1} \mathrm{H}$ NMR $\left(400 \mathrm{MHz} ; \mathrm{CDCl}_{3}\right) \delta_{\mathrm{H}}: 2.95(1 \mathrm{H}$, dd, $J$ 7.3, H2), $3.05(1 \mathrm{H}, \mathrm{dd}, J$ 7.3, 0.8, H3), $3.78(1 \mathrm{H}, \mathrm{m}, \mathrm{H} 1), 4.00(1 \mathrm{H}, \mathrm{m}, \mathrm{H} 4), 5.86(1 \mathrm{H}, \mathrm{s}, \mathrm{OH})$, $6.16(1 \mathrm{H}, \mathrm{dd}, J 3.4,1.0, \mathrm{H} 6), 6.87-7.60$ (16H, m, Ar), $7.93(1 \mathrm{H}, \mathrm{s}, \mathrm{NH}), 8.44(1 \mathrm{H}, \mathrm{m}, \alpha \mathrm{Pyr}), 8.49$ $(1 \mathrm{H}, \mathrm{m}, \alpha \mathrm{Pyr}) ;{ }^{13} \mathrm{C} \mathrm{NMR}\left(100 \mathrm{MHz} ; \mathrm{CDCl}_{3}\right) \delta_{\mathrm{C}}$ : 47.95 (C1), $48.8(\mathrm{C} 4), 49.2(\mathrm{C} 3), 50.35(\mathrm{C} 2)$, 78.7 (quat., $\mathrm{C}-\mathrm{OH}), 121.7(\mathrm{CH}, \mathrm{Ar}), 122.1(\mathrm{CH}, \mathrm{Ar}), 122.7(\mathrm{CH}, \mathrm{Ar}), 123.9(\mathrm{CH}, \mathrm{Ar}), 126.5$ (quat.), $126.9(\mathrm{CH}, \mathrm{Ar}), 127.4(\mathrm{CH}, \mathrm{Ar}), 127.5(\mathrm{CH}, \mathrm{Ar}), 128.0(\mathrm{CH}, \mathrm{Ar}), 128.4(\mathrm{CH}, \mathrm{Ar}), 129.2$ (CH, Ar), 135.1 (C6), 136.1 (CH, Ar), 136.9 (CH, Ar), 138.6 (quat.), 142.8 (quat.), 148.1 (quat.), 148.2 ( $\mathrm{CH}, \mathrm{Ar}$ ), 149.1 ( $\mathrm{CH}, \mathrm{Ar}), 156.35$ (quat.), 158.0 (quat.), 160.95 (quat.), 176.7 (quat., $\mathrm{C}=\mathrm{O}$ ), 176.9 (quat., $\mathrm{C}=\mathrm{O}$ ).

cis-exo-threo-5-( $\alpha$-Hydroxy- $\alpha$-2-pyridylbenzyl)-7-( $\alpha$-2-pyridylbenzylidene)-5-norbornene-

2,3-dicarboximide (1e) (R). The mother liquor obtained from recrystallization of the crude sample of 1 from ethyl acetate, was concentrated and the resultant residue purified by repeated column chromatography (ethyl acetate/ chloroform 7:3) and recrystallized from ethyl acetate to give isomer 1e as a white solid: Mp $188-189^{\circ} \mathrm{C}\left(\right.$ lit. $\left.^{6} 188-190{ }^{\circ} \mathrm{C}\right) ;{ }^{1} \mathrm{H} \mathrm{NMR}\left(400 \mathrm{MHz} ; \mathrm{CDCl}_{3}\right)$ $\delta_{\mathrm{H}}: 2.98(1 \mathrm{H}, \mathrm{dd}, J 7.3,0.8, \mathrm{H} 2), 3.42(1 \mathrm{H}, \mathrm{dd}, J 7.3,0.9, \mathrm{H} 3), 3.74(1 \mathrm{H}, \mathrm{m}, \mathrm{H} 1), 4.11(1 \mathrm{H}, \mathrm{m}$, H4), $5.75(1 \mathrm{H}, \mathrm{dd}, J 3.5,1.1, \mathrm{H} 6), 6.52(1 \mathrm{H}, \mathrm{s}, \mathrm{OH}), 6.93-7.65(16 \mathrm{H}, \mathrm{m}, \mathrm{Ar}), 8.07(1 \mathrm{H}, \mathrm{s}, \mathrm{NH})$, $8.54(2 \mathrm{H}, \mathrm{m}, \alpha \mathrm{Pyr}) .{ }^{13} \mathrm{C} \mathrm{NMR}\left(100 \mathrm{MHz} ; \mathrm{CDCl}_{3}\right) \delta_{\mathrm{C}}: 48.1(\mathrm{C} 1), 48.9(\mathrm{C} 4), 49.6(\mathrm{C} 3), 49.9(\mathrm{C} 4)$, 78.9 (quat., C-OH), $121.9(\mathrm{CH}, \mathrm{Ar}), 122.4(\mathrm{CH}, \mathrm{Ar}), 122.5(\mathrm{CH}, \mathrm{Ar}), 124.3(\mathrm{CH}, \mathrm{Ar}), 125.8$ (quat.), $127.1(\mathrm{CH}, \mathrm{Ar}), 127.3(\mathrm{CH}, \mathrm{Ar}), 127.4(\mathrm{CH}, \mathrm{Ar}), 128.0(\mathrm{CH}, \mathrm{Ar}), 128.4(\mathrm{CH}, \mathrm{Ar}), 129.3$ (CH, Ar), 133.4 (C6), $136.3(\mathrm{CH}, \mathrm{Ar}), 136.8$ (CH, Ar), 138.7 (quat.), 143.2 (quat), $147.4(\mathrm{CH}$, $\mathrm{Ar}$ ), 148.3 (quat.), 148.9 ( $\mathrm{CH}, \mathrm{Ar}$ ), 157.3 (quat.), 157.9 (quat.), 161.6 (quat.), 177.0 (quat., $\mathrm{C}=\mathrm{O}$ ), 177.1 (quat., $\mathrm{C}=\mathrm{O}$ ).

\section{trans-exo-threo-5-( $\alpha$-Hydroxy- $\alpha$-2-pyridylbenzyl)-7-( $\alpha$-2-pyridylbenzylidene)-5-}

norbornene-2,3-dicarboximide (1f) (T). The mother liquor obtained from recrystallization of the crude sample of $\mathbf{1}$ from ethyl acetate, was concentrated and the resultant residue purified by repeated column chromatography (ethyl acetate/ chloroform 7:3) and recrystallized from ethyl acetate to give isomer $\mathbf{1 f}$ as a white solid: $\mathrm{Mp} 231-232{ }^{\circ} \mathrm{C}$ (lit. $\left.{ }^{6} 230-231{ }^{\circ} \mathrm{C}\right) ;{ }^{1} \mathrm{H}$ NMR (400 MHz; 
$\left.\mathrm{CDCl}_{3}\right) \delta_{\mathrm{H}}: 2.90(1 \mathrm{H}, \mathrm{dd}, J$ 7.3, 0.8, H2), $3.27(1 \mathrm{H}, \mathrm{dd}, J$ 7.3, 0.9, H3), $3.79(1 \mathrm{H}, \mathrm{m}, \mathrm{H} 4), 4.37$ $(1 \mathrm{H}, \mathrm{dt}, J 3.4,1.2, \mathrm{H} 1), 5.76(1 \mathrm{H}, \mathrm{dd}, J 3.4,1.0, \mathrm{H} 6), 6.19(1 \mathrm{H}, \mathrm{s}, \mathrm{OH}), 6.90-7.62(16 \mathrm{H}, \mathrm{m}, \mathrm{Ar})$, $7.89(1 \mathrm{H}, \mathrm{s}, \mathrm{NH}), 8.54(1 \mathrm{H}, \mathrm{m}, \alpha \mathrm{Pyr}), 8.59(1 \mathrm{H}, \mathrm{m}, \alpha \mathrm{Pyr}) .{ }^{13} \mathrm{C} \mathrm{NMR}\left(100 \mathrm{MHz} ; \mathrm{CDCl}_{3}\right) \delta_{\mathrm{C}}: 47.4$ (C1), 49.3 (C4), 49.5 (C3), 50.5 (C2), 78.4 (quat., C-OH), 121.8 (CH, Ar), 122.5 (CH, Ar), 122.6 (CH, Ar), $124.2(\mathrm{CH}, \mathrm{Ar}), 126.55$ (quat.), $127.0(\mathrm{CH}, \mathrm{Ar}), 127.4(\mathrm{CH}, \mathrm{Ar}), 127.6(\mathrm{CH}, \mathrm{Ar}), 128.2$ $(\mathrm{CH}, \mathrm{Ar}), 128.3(\mathrm{CH}, \mathrm{Ar}), 129.3(\mathrm{CH}, \mathrm{Ar}), 133.0(\mathrm{C} 6), 136.1(\mathrm{CH}, \mathrm{Ar}), 136.7(\mathrm{CH}, \mathrm{Ar}), 138.5$ (quat.), 143.2 (quat.), 147.3 (CH, $\mathrm{Ar}), 148.1$ (CH, Ar), 149. 1 (CH, Ar), 155.9 (quat.), 158.1 (quat), 160.1 (quat.), 176.6 (quat., $\mathrm{C}=\mathrm{O}$ ), 176.8 (quat., $\mathrm{C}=\mathrm{O}$ ).

\section{References}

1. Roszkowski, A. P. J. Pharm. Exp. Ther. 1965, 149, 288.

2. Przyborowski, T.; Hillar, M. Biul. Inst. Med. Morsk Gdansk 1968, 19, 211.

3. Rennison, B. D.; Hammond, L. E.; Jones, G. L. J. Hygiene 1968, 66, 147.

4. Bova, S.; Trevisi, L.; Cima, L.; Luciani, S.; Golovina, V.; Cargnelli, G. J. Pharm. Exp. Ther. 2001, 296, 458.

5. Bova, S.; Cima, L.; Golovina, V.; Luciani, S.; Cargnelli, G. Cardiovasc. Drug Rev. 2001, 19, 226.

6. Mohrbacher, R. J.; Almond, H. R.; Carson, E. L.; Rosenau, J. D.; Poos, G. I. J. Org. Chem. 1966, 31, 2141.

7. Roszkowski, A. P.; Poos, G. I.; Mohrbacher, R. J. Selective Rat Toxicant. Science 1964, $144,412$.

8. Mohrbacher, R. J.; Paragamian, V.; Carson, E. L.; Puma, B. M.; Rasmussen, C. R.; Meschino, J. A.; Poos, G, I. J. Org. Chem. 1966, 31, 2149.

9. Davis, J. C., Jr.; Van Auken, T. V. J. Am. Chem. Soc. 1965, 87, 3900.

10. Abraham, R. J.; Fisher, J. Magn. Res. Chem. 1985, 23, 856.

11. Abrahamsson, S.; Nilsson, B. J. Org. Chem. 1966, 31, 3631.

12. Nilsson, B. Acta Chem. Scandinavica 1968, 22, 518.

13. Poos, G. I.; Mohrbacher, R. J.; Carson, E. L.; Paragamian, V.; Puma, B. M.; Rasmussen, C. R.; Roszkowski, A. P. J. Med. Chem. 1966, 9, 537. 